\title{
Economic Empowerment of Pesantren Through Agribusiness (Study On Al-Mawaddah Entrepreneurial Pesantren)
}

\author{
Muhammad Baqi Mustaghfiri \\ Institut Agama Islam Negeri Salatiga \\ email: muhammadbaqimustaghfiri@gmail.com
}

\begin{abstract}
This paper aims for several research objectives. It aims to find out the agribusiness sectors developed by Al-Mawaddah Entrepreneurial Pesantren. It also aims to find out the empowerment of agribusiness developed by this pesantren. Last, it also aims to determine the impact of empowering agribusiness developed on improving the economy Al-Mawaddah Entrepreneurial Pesantren's alumni. This research is a field research. The approach used by researcher is a qualitative descriptive approach with a case study strategy. Research location is at Pesantren Entrepreneur AlMawaddah Honggosoco Kudus RT. 06/ RW. 01, Jekulo District, Kudus Regency. Data collection techniques used are observation, interviews, and documentation. The data analysis technique used is descriptive qualitative. The results show that: (1) the agribusiness sector that was developed at Al-Mawaddah Entrepreneurial Pesantren touched only agriculture and educational sectors; (2) Agribusiness Empowerment developed by Al-Mawaddah Entrepreneurial Pesantren consists of three stages, namely: input, process, and output; (3) Agribusiness entrepreneurship is better than working under other people.
\end{abstract}

Keywords: Economic Empowerment, Pesantren, Agribusiness.

\section{INTRODUCTION}

Pesantren (Islamic boarding school entities) as educational institutions is indeed familiar in Islamic scientific studies, especially in Indonesia. Pesantren is one of the centers of science 
that contributes a lot to the development of Indonesian science, such as national defense, economy, social culture and specifically on religious matters. In its development, pesantren experienced a paradigm shift from an institution that had relied on religious education to become an institution which generates reliable human resources who are able to create jobs.

This paradigm shift requires pesantren to direct their development in the economic field. As a result, there appears a typology of pesantren based on the characteristics of pesantren. Various types of pesantren that emerge in the community are classified into three types, namely Traditional Pesantren or salaf Islamic Boarding Schools, Modern Pesantren called khalaf Islamic boarding schools, and Comprehensive Islamic Boarding Schools (a combination of salaf and khalaf) (Ghazali, 2002).

One of those three type pesantren that appears in the community is Al-Mawaddah Entreprenurial Pesantren, Honggosoco, Kudus Regency. This pesantren can be categorized as a comprehensive type of pesantren. This can be seen in the application of the concept of education that refers to the spirit of Sunan Kudus, known as the spiritual, leadership, and entrepreneur. In addition to religious learning as it applies generally in salaf pesantren, santri (students of pesantren) is also trained in entrepreneurship program and business units developed by AlMawaddah Entreprenurial Pesantren. Some of the business units include: travel agency, umroh agency, educational tour, shop, pertamini, beverage shop, and weighbridge.

In the agribusiness sector, Al-Mawaddah Entreprenurial Pesantren developed the concept of an integrated farming system (Roziki, 2016). Agribusiness business units are developed ranging from food crop cultivation, plantations, dragon fruit gardens, hydroponic houses and culinary products made from local raw materials and expands to sugar cane land management in collaboration with five sugar companies. It also expands to the management of cassava land for the production of PT. Indofood (Nashr, 2018).

From the business activities that developed by the pesantren, every month a student can get a monthly income. The amount of 
income depends on the performance of the students, the highest is reaching 5-6 million rupiah a month. Thus, students can fulfill their daily needs independently. Based on this management system, pesantren applies rule where students who have been accepted at the Al-Mawaddah Entrepreneurial Pesantren are not allowed to receive remittances from parents. For its seriousness in training its santri's entrepreneurship, pesantren won the Santri Of The Year 2018 award for the pesantren entrepreneur category. The award was received from Islam Nusantara Center at UIN Sunan Ampel Surabaya. Previously the pesantren also received the Adhikarya Pangan Nusantara award from the Ministry of Agriculture, and the Kalpataru Award (Nashr, 2018).

\section{LITERATURE REVIEW}

Literature review is a study of theories obtained from related literatures that will support this research. Several studies on pesantren economic empowerment have been carried out by academics. For example, (Sunarsih, Rahmawati, \& Qamaruzzaman, 2013) conducted research on "Development of Sharia-Based Entrepreneurship Culture to Create Entrepreneurs from Santri Environments in Islamic Boarding Schools in Jember Regency". The author uses the Turla and Hawkins research method to identify the potential abilities of students' entrepreneurial culture by distributing questionnaires to 9 kopontren (pesantren's cooperative unit) as research objects. As a result, students and boarding school administrators have entrepreneurial potential, but at different levels. 5 kopontrens require the sharpening of entrepreneurial instincts, while the other 4 require an increase of prudence in moving forward. This shows that students need education and training in entrepreneurship development.

The other research was done by (Wahid, 2011) on "Economic Empowerment of Islamic Boarding Schools: Case Study of Nurul Mursyidah Islamic Boarding School Pandegelang." The results of the study indicate that there are policies from pesantren in focusing economic sector to be developed by pesantren. There is also policy on the stage of strengthening students' creativity about fishery livestock. 
The other research was done by (Ulfa, 2015) on, "Santri Entrepreneurial Interests and Factors That Influence It" which carried out Ar-Riyadh Islamic Boarding School in Palembang as the objectThe research method used in that paper is quantitative through questionnaire technique. The research describes the intensity of entrepreneurship among senior students of ArRiyadh Palembang which found to be very high for conducting entrepreneurship in pesantren. This high interest is influenced by several internal and external factors.

The other research was done by (Sulaiman, Masrukin, \& Chusmeru, 2016) on "Empowering Islamic Boarding School Cooperatives as Santri Social and Economic Education". The research aims to analyze the empowerment of the Islamic Boarding School Cooperative (Kopontren) as a social and economic education of students. The study used Participatory Learning and Action (PLA) method. Data collection was done through interviews, direct observation, Focus Group Discussion (FGD) and documentation. The selection of informants was done by purposive sampling. The informants include chairman, management and members of the Kopontren. Research locations is in the Islamic Education Foundation (YPAI) Darussalam Islamic Boarding School in Hamlet Waluh, Banyumas and El Bayan 1 Majenang, Cilacap. Research uses interactive analysis. The results showed (1) Kopontren Management has a high determination and enthusiasm to improve management, membership and develop business units as social and economic education for the independence of students. (2) Kopontren needs support from the head of the boarding school and the participation of all students to become Kopontren members and cadres. (3) Kopontren needs empowerment programs such as counseling, training and assistance on institutional management, management, membership and finance.

Another study was conducted by (Chusmeru, Masrukin, \& Pangestuti, 2017) on "Islamic Boarding School Cooperatives as Santri Economic Empowerment". The study used the Participatory Learning and Action (PLA) method and while the selection of of informants was done through purposive sampling. 
The sample consists of students, religious teachers, and boarding school board members. Data collection was done by interview, observation, documentation and Focus Group Discussion (FGD) as well as interactive analysis. The research location was in ElBayan Majenang Kopontren Cilacap district. The results showed that the strategy of kopontren in the economic empowerment of students is very important by improving institutional management, membership, management, finance, partnerships and the development of agribusiness-based business units to improve the welfare of Islamic boarding schools, students and the community.

Another study was conducted by (Bustomi \& Umam, 2017) with the title: "Strategies for Empowering Santri and Community Economic Empowerment in the Cirebon City Boarding School Entrepreneurship Environment". This type of research uses qualitative approach using case study strategy. The results of this study mentions that the strategy of economic empowerment through Islamic boarding school business units consists of: goat farms, catfish farming, and plantations. Santri was also given the opportunity to undergo internships in several business units in boarding school partners. The pesantren also empowered the economy through entrepreneurship training involving the society and a number of students. In its implementation the main factors that hamper economic empowerment are the limited number of students, lack of teaching staff, differences in learning methods, and the lack of entrepreneurial spirit among the community.

There is also another study done by (Ningsih, 2017) on „Economic Empowerment of Islamic Boarding Schools Through the Development of Local Resources (Study at Daarut Tauhid Islamic Boarding School)“. This article writes the role of pesantren in local resource-based economic empowerment in the era of development. This aims to determine the institutional form of the pesantren and its impact on the existence of the pesantren and to find out the pesantren's economic system that is appropriate and relevant to be applied in maintaining the existence of the pesantren. The study is carried out through literature and field study to find out a detailed description of the aspects that will be studied using qualitative approach. The results of the analysis 
illustrate that pesantren, as a „cultural institution“ that was born on the initiative of independent community is a strategic potential that exists in the midst of community life since the beginning of its emergence. Even though there are many pesantren that position themselves (only) as educational and religious institutions, but until now some pesantren have tried to reposition themselves in dealing with various social problems of society, such as economic, social and political. Therefore, pesantren are required to make updates that can optimize the potential they have. Specifically, in community empowerment through the economy.

The last is research by (Ansor, 2019) on „Kiai's Strategy in Santri Empowerment at Apis Sanan Gondang Blitar Islamic Boarding School Blitar." Pesantren as Islamic educational institutions are not only required to prepare religious scholars and preaching students but also as a stronghold of the people and community development in various sectors of life. Because of that, pesantren need to develop themselves into a hub for social based economic as pesantren has such strenght. The Kiai as the top leader of the pesantren must be able to analyze the resources of the santri in order to become a qualified HR. To achieve this goal, the Kiai's strategy in empowering students in Apis Sanan Gondang Blitar Islamic Boarding School are: (a) establish a mission to provide life skills to students in the form of cooperatives and skills programs, (b) deliberations in all forms of student empowerment programs, (c) establishing clarification in resolving problems or organizational conflicts, both at the top level (leadership's decision) or subordinates (d) role models.

The studies above are researches conducted in pesantren that develop the economy using the model of economic empowerment through entrepreneurship. Various strategies have been carried out in improving the pesantren economy, but the main factor that has become the problem of empowering the pesantren economy is the problem of human resources (HR) as an insufficient economic agent. In the author's perspective, the Al-Mawaddah Entrepreneur Boarding School Honggosoco Jekulo Kudus is very relevant as an object of pesantren economic empowerment research. Because since its establishment in 2008, Al-Mawaddah has developed 
various business units covering several fields, especially in agribusiness. Even more interesting, with the existence of pesantren business units, santri income reaches millions of rupiah. Of course this is not a small income for a santri, with that income santri can independently in meeting their daily needs.

\section{THEORITICAL FRAMEWORK}

The theoretical framework model in this study can be described as follows:

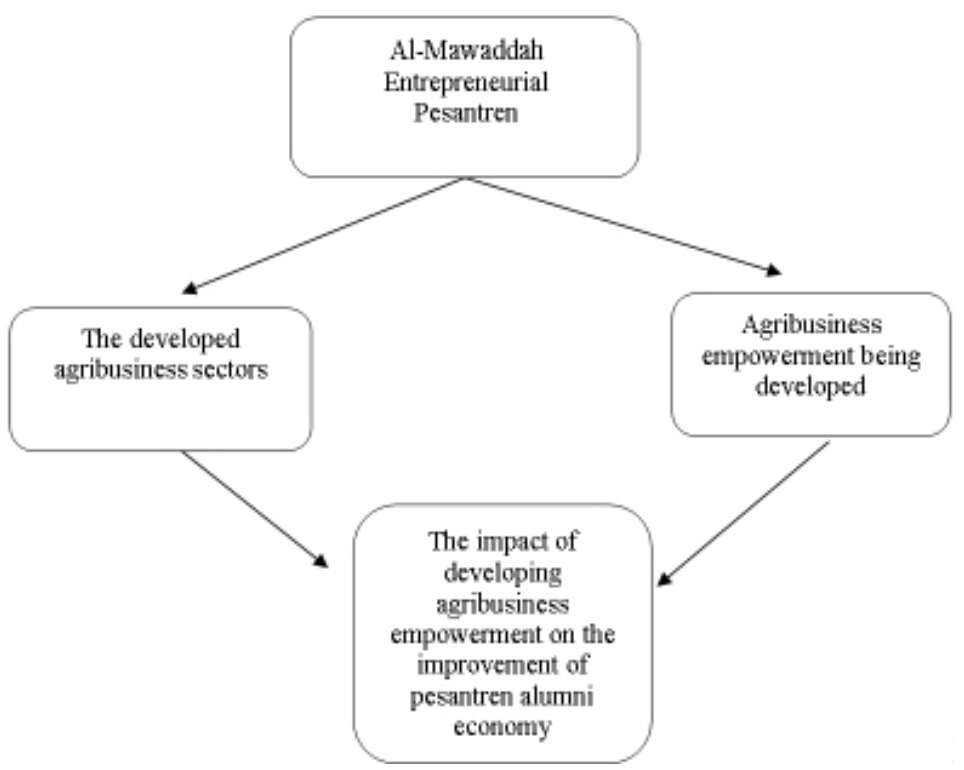

The Model of Theoritical Framework

\section{RESEARCH METHODOLOGY}

This research is a field research. Field research is one of the studies with an intensive, detailed and in-depth approach. This type of research makes an object as a case that exists in a community or agency environment (Moeloeng, 2005). The approach used in this research is a qualitative descriptive approach with a case study strategy. Case studies are research strategies in which researchers carefully investigate a program, event, activity, process, or group of individuals. 
The data needed is qualitative data. Data sources needed are primary data and secondary data. Primary data were obtained from observations of the pesantren agribusiness sector and interviews with informants including the founder and caregiver of the pesantren boarding school, santri, agribusiness management, and several communities around the boarding school. Secondary data used are books, thesis, journals, and data derived from Pesantren.

\section{Data Collection Technique}

1. Observation

Observation is a data collection tool that is done by observing and recording systemically the phenomenon being investigated (Narbuko \& Ahmadi, 2007). Observation is also one of technique done through observing the object being studied. In this case the researcher uses non-participant observation, which only sees and listens to certain situations without active participation in it (Emzir, 2012) or better known as passive participatory observation (Sugiyono, 2014).

This observation was conducted to obtain data from information from actual situation, in which the researcher observes what agribusiness sectors were developed by AlMawaddah Entreprenurial Pesantren and their activities. By doing so, researchers can get an idea of the agribusiness system developed by pesantren.

2. Interview

Interview is a question and answer process in research that takes place verbally where two or more people face to face, listen directly to information or further information (Narbuko \& Ahmadi, 2007). Through this interview, the researcher intends to obtain historical data on the pesantren, find out the agribusiness sectors developed by the pesantren, the agribusiness empowerment developed by the pesantren, and the impact of developing agribusiness empowerment on the economic improvement of Al-Mawaddah Entrepreneurial Pesantren. 
3. Documentation

Documentation is a search for data about things or variables in the form of notes, transcripts, books, newspapers, magazines, minutes, inscriptions, laggers, agendas, etc, (Subagyo, 1991). The collected documents are then selected and adjusted to the purpose and focus of the problem.

\section{Data Analysis Technique}

In general, qualitative research uses a lot of analytical models in analyzing data that are coined by Miles and Huberman which are often referred to as interactive data analysis methods. There are three activities in qualitative data analysis, namely the stage of data reduction, data display, and conclusions or verification (Sugiyono, 2006).

1. Data Reduction

The researcher records all data objectively according to the findings in the field. Data in this study were collected using documentation study techniques.

2. Data Display

After the data has been reduced, the second step is to present the data. At this stage the researcher records the data obtained from the field carefully, summarizes, selects the main points, and focuses on the important matters. Through the presentation of these data, the data is organized and arranged in a relationship pattern, so that it will be more easily understood.

3. Drawing Conlcusions

The third step in data analysis in qualitative research according to Miles and Huberman is drawing conclusions. The initial conclusions put forward are still temporary, and will change if no strong evidence is found to support the data collection stage.

\section{RESULT AND DISCUSSION}

Al-Mawaddah Islamic Boarding School (Pesantren) is located in Honggosoco Village, Rt $06 \mathrm{Rw}$ 01, Jekulo District, Kudus Regency. This boarding school is located next to its 
manager which is near to the road to STAIN Kudus so it is easy to reach. Geographically, the location of al-Mawaddah Islamic Boarding School in the north is bordered by vast fields, in the east it is bordered by a house with a pharmacy, in the south it is bordered by Baitul Mu'minin Mosque and in the west it is bordered by the Kiai Miftahuddin house and MTs-MA Hasyim Asy'ari 03 Honggosoco Jekulo Kudus.

Al-Mawaddah Islamic Boarding School was founded around 2008 by KH. Sofyan Hadi, Lc., M.A who was studied Sharia and Law at al-Azhar Cairo, then proceeded for post graduate at the Faculty of Interregious and Cross-Cultural Studies UGM Yogyakarta. It is obvious that KH. Sofyan Hadi, Lc., M.A is not alone in establishing Al-Mawaddah. It was also the encouragement and determination of his wife $\mathrm{Hj}$. Siti Khodijah al-Hafidzah, alumni of the Yanbu'ul Quran Islamic Boarding School Kudus. The establishment of Al-Mawaddah is with an aim of serving God using da'wah. That determination IRlstalso assisted by a group of people, one of whom was his own parents.

Al-Mawaddah Pesantren has a vision of "Becoming a global institution that encourages the birth of a noble successful civilization" while its mission is: "To inspire and provide the best thing in the process of empowerment to reach the highest achievement, based on universal principles and local wisdom". Based on this missionn, Al-Mawaddah also accommodates the local wisdom possessed by Kudus society in carrying out their education. It carries out the teachings of Sunan Kudus about GUSJIGANG which is an acronym of: bagus akhlak lan budine, pinter ngaji lan dagang. This acronym is actually a Javanese language. This acronym means:

Gus (bagus or good). Through the word "gus" it is hoped that the santri will always instill and actualize good and virtuous attitudes and behavior in their social lives.

$J i$ (ngaji or learning Islamic teaching). The students are then taught about religious knowledge, so that students have a deep understanding of religious sciences and technology as their provisions to live happily in the world and the hereafter.

Gang (dagang or trading). Trading is an activity carried out 
by the Prophet Muhammad in the past, and also activities carried out by the wali, one of which is Sunan Kudus. Through trading activities people will benefit. This will encourage everyone to keep on trying to get a reward for what they have been trying.

Al-Mawaddah combines formal and non-formal education in presenting education with the aim to change those uncapable of doing things to be good in it. Particularly, Al-Mawaddah emphasizes entrepreneurship in this boarding school.

The number of santri studying at Al-Mawaddah Islamic Boarding School is 30 students. Most of the students come from around Kudus, some from districts in Java and outside Java and others even come from East Kalimantan. The number of students enrolled is indeed limited because it is designed for producing great pesantren alumni in the field of entrepreneurship. While the number of teacher (Kyai) is 8 people, namely KH. Sofyan Hadi, Lc., M.A, Nyai Hj. Siti Khodijah, KH. Miftahuddin, Ustadz Khaiyuddin, Ustadz Mu'taddin Ali, Ustadz Rasyidi, Ustadz Nur Said, M.A., M.Ag, Ustadz Ersyad Qomar, ST.

In an institution, whether it is an educational institution or others, it certainly has a clear management structure. Management structure is useful to facilitate the sustainability of an institution or organization. Likewise, Al-Mawaddah Islamic Boarding School also has a clear management structure, each of which has clear different functions, stewardship and performance but remains within one goal.

Agribusiness sector is one of the targeted sectors in entrepreneurship education at Al-Mawaddah. Through entrepreneurship education in the field of agribusiness, it is expected that the students have adequate abilities, ranging from land management, crop cultivation, to marketing activities. The ultimate goal of all education is basically that students can live independently, without relying on other parties (looking for work) after graduating from pesantren by pursuing agribusiness sector that has been taught.

The agribusiness sector that was developed at Al-Mawaddah Entrepreneur Boarding School up to today, has only touched the agricultural sector as well as education and yet to touch other 
agribusiness sectors such as: fisheries or animal husbandry. However, theory of the other two agribusiness sectors are also taught.

The agricultural sector developed includes (1) agricultural food crops, such as: rice, corn, soybeans, vegetables, and cassava; (2) fruit crops, such as: longan, and dragon fruit (3) plantation crops, such as sugar cane. The choice of plants cultivated in the pesantren has basically also been made with careful consideration. For example: rice because people eat rice everyday so the need for rice gradually increases. Therefore, rice becomes one of the choices of plants that is developed by pesantren. Santri are also taught how to cultivate, process, and even its marketing strategy.

Another interesting thing at the pesantren is that the students were not only taught traditional cultivation of plants, but the students were also taught to carry out modern crop cultivation including using hydroponic techniques. This technique is very useful. Apart that students being able to take advantage of the small piece of land, the students can also produce fresher vegetable crops. So in this case, the hydroponic technique taught is to cultivate vegetable crops. For the needs of the land, basically the Pesantren that provides it. It comes either through land owned by the Pesantren or by renting land owned by farmers around boarding school.

What is taught by Al-Mawaddah Entreprenuerial Pesantren mentioned above makes agriculture as an attractive and profitable business system. Agribusiness can not only rely on one part of the system that runs in it. A sugar cane plantation, for example, will not experience success if it only pays attention to or focuses on the process of increasing and improving production alone while ignoring the marketing factors. A good and attractive quality sugar cane will only become junk if not accompanied by good marketing, ecause no one buys it. Therefore, agribusiness is a system that must be run as a whole in an integrated and harmonious way.

What was stated above when it was related to the opinion of Isbandi Rukminto Adi, it can be inferred that the empowerment efforts carried out by al-Mawaddah Entrepeneurial 
Pesantren through some ways : (1) Growing people's desire for entrepreneurship, struggling in economic aspects, acting by designing the discussions about the problem in society, (2) Providing information about the experiences of other groups that have been successful and prosperous, (3) Helping the community to make an analysis of the business situation prospective systematically about the nature and causes of business problems, (4) Connecting people with resources that can be utilized (Bariadi, Zen, \& Hudri, 2005).

Meanwhile, if it is associated with Mardikanto's opinion, the agribusiness empowerment developed by al-Mawaddah Entrepreneurial Pesantren is carried out through 3 (three) stages, namely input, process and output. First, input is to determine and analyze the needs of empowerment through identifying needs and setting targets. This is intended to achieve goals that can be measured in the form of improvement and better change. Second, the process is the implementation of planned empowerment programme. Third, output is monitoring, evaluating and analyzing empowerment. The explanation of the three process in the context of Al-Mawaddah Entrepreneurial Pesantren is as follows: 


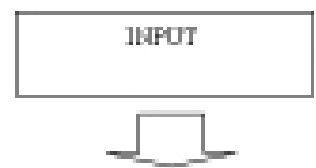

1. Planning cald determining the types of pleats to be cultirated

2. Preparing the land needod.

3. Determining which peeties an be imrited to cooperate in imporing agicaltural siantific krowellyt ind procesang of agriculurd jcodocts

4. Planning entreperesurship materid thet needs to be given to tudants.

5. Planning how to motiwte the tudanis 20 that they have a high interest in the fidd of agribuanes entreperensurstip.

6. Planning how to assis and eviluate agribuanes entregcenourctip activities

T. Despring peay that can support spiritud strangth so that sudants hare a high interest in the fidd of conitusines entrepervarship

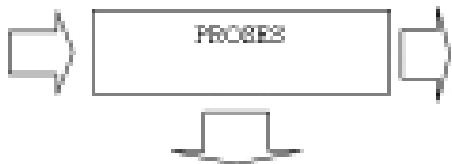

1. Imiting offides from the Kudus Regency Agriculture Office to improve agrialtuad toturial knowletye

2. Imriting SMEs prodicianars (induang sontri dumri)

3. Encorraganert from the head of Peantren erery and of the suder an the importance of agibuainess antrepranership.

4. Giving tasks for antri to implement thair toturial vonuletge on equlowinass on their deily live

5. The had of pesaniren and its marager provides preyer for the piritual strangth.

\section{CONCLUSION}

From the analysis that have been done, the following conclusions can be drawn:

1. The agribusiness sector developed at the Al-Mawaddah Entrepreneur Pesantren in Honggosoco Kudus has so far only touche the agriculture and tourism sectors, not yet to other agribusiness sectors, such as fisheries or livestock. The agricultural sector developed includes: agricultural food crops, such as: rice, corn, soybeans, vegetables, and cassava; fruit plants, such as: longan, and dragon fruit; even in the cottage also developed plantation crops, such as sugar cane.

2. Agribusiness Empowerment developed by al-Mawaddah 
Entrepreneur Pesantre consists of 3 (three) stages, namely: input, process, and output. At the input stage AlMawaddah Entrepeneur Pesantren carrries out various planning processes, namely: planning and determining the types of plants to be cultivated, preparing the land needed. determining which parties can be invited to cooperate in improving agricultural scientific knowledge and processing of agricultural product, planning for entrepreneurship material that needs to be given to students, planning how to motivate the students so that they have a high interest in the field of agribusiness entrepreneurship, planning how to assist and evaluate agribusiness entrepreneurship activities, designing pray that can support spiritual strength so that students have a high interest in the field of agribusiness entrepreneurship. In the process step, Al-Mawaddah Enterpreneurial Pesantren has many activities including: inviting officials from the Kudus Regency Agriculture Office to improve agricultural technical knowledge, inviting SMEs practicioners (including santri alumni), encouragement from the head of Pesantren every end of the study on the importance of agribusiness entrepreneurship, giving tasks for santri to implement their technical knowledge on agribusiness on their daily live, the head of pesantren and its manager provides prayer for the spiritual strength. In the output stage, this pesantren has many activities as well including: the head of pesantren and its manager provide assistance, the head of pesantren, its manager along with santri evaluate agribusiness activities that has been done.

3. Agribusiness empowerment conducted by al-Mawaddah Entrepreneurial Pesantren is able to improve the alumni economy through agribusiness entrepreneurship. The results also show that agribusiness entrepreneurship is better than working with other people (companies). Because in addition to providing freedom (not bound), from the aspect of income generated is also higher. 


\section{REFERENCES}

Ansor, M. S. (2019). Strategi Kiai dalam Pemberdayaan Santri di Pondok Pesantren Apis Sanan Gondang Blitar. Jurnal Pendidikan: Riset Dan Konseptual, 3(2), 128-136.

Bariadi, L., Zen, M., \& Hudri, M. (2005). Zakat dan Wirausaha. Jakarta: CV. Pustaka Amri.

Bustomi, I., \& Umam, K. (2017). Strategi Pemberdayaan Ekonomi Santri dan Masyarakat di Lingkungan Pondok Pesantren Wirausaha Lantabur Kota Cirebon. Al-Mustashfa: Jurnal Penelitian Hukum Ekonomi Islam, 2(1), 79-90.

Chusmeru, Masrukin, \& Pangestuti. (2017). Koperasi Pondok Pesantren Sebagai Pemberdayaan Ekonomi Santri. In Prosiding Seminar Nasional dalam Pengembangan Sumber Daya Perdesaan dan Kearifan Lokal Berkelanjutan VII. Purwokerto.

Emzir. (2012). Metodologi Penelitian Kualitatif. Jakarta: Rajawali Press.

Ghazali, B. M. (2002). Pesantren Berwawasan Lingkungan. Jakarta: Prasasti.

Moeloeng, L. J. (2005). Metode Penelitian Kualitatif. Bandung: Remaja Rosdakarya.

Narbuko, C., \& Ahmadi, A. (2007). Metodologi Penelitian. Jakarta: Bumi Aksara.

Nashr, J. A. (2018, October 31). Ponpes Al-Mawaddah Peraih Santri Of The Year: Nyantri di Pesantren Tidak Boleh Menerima Kiriman dari Orang Tua. Radar Kudus Jawa Pos. Retrieved from https://radarkudus.jawapos.com/ $\mathrm{read} / 2018 / 10 / 31 / 101214 /$ nyantri-di-pesantren-tidak-bolehmenerima-kiriman-dari-orang-tua

Ningsih, T. R. (2017). Pemberdayaan Ekonomi Pesantren Melalui Pengembangan Sumber Daya Lokal. Lembaran Masyarakat: Jurnal Pengembangan Masyarakat Islam, 3(1), 57-78.

Roziki, Y. I. (2016, October 31). Kunjungi Ponpes Al-Mawaddah 
Kudus, Puluhan Mahasiswa Asing Terkagum-kagum. Tribunnews. Retrieved from https://www.tribunnews. com/regional/2016/10/31/kunjungi-ponpes-al-mawaddahkudus-puluhan-mahasiswa-asing-terkagum-kagum

Subagyo, J. (1991). Metode Penelitian dalam Teori dan Praktek. Jakarta: Rinek Cipta.

Sugiyono. (2006). Statistika Untuk Penelitian. Bandung: Alfabeta.

Sugiyono. (2014). Memahami Penelitian Kualitatif. Bandung: Alfabeta.

Sulaiman, Masrukin, \& Chusmeru. (2016). Pemberdayaan Koperasi Pondok Pesantren Sebagai Pendidikan Sosial dan Ekonomi Santri. Jurnal Pendidikan Dan Pemberdayaan Masyarakat, 3(2), 109-121.

Sunarsih, Rahmawati, R., \& Qamaruzzaman, B. (2013). Pengembangan Budaya Kewirausahaan Berbasis Syariah Untuk Menciptakan Pengusaha dari Lingkungan Santri Pada Pondok Pesantren di Kabupaten Jember. Relasi, 1(1), $1-18$.

Ulfa, N. (2015). Minat Wirausaha Kaum Santri dan Faktor-Faktor Yang Mempengaruhinya (Studi Pada Pondok Pesantren ArRiyadh Palembang). I-ECONOMICS: A Research Journal on Islamic Economics, 1(1), 91-121.

Wahid, K. (2011). Pemberdayaan Ekonomi Pesantren: Studi Kasus Pesantren Nurul Mursyidah Pandeglang. Edukasi, 9(1). https://doi.org/10.32729/edukasi.v9i1.280 